\title{
Large ungulates from the basal Oligocene of Oman: 2 - Proboscidea
}

\author{
Martin PICKFORD
}

Sorbonne Universités - CR2P, MNHN, CNRS, UPMC - Paris VI, 8, rue Buffon, 75005, Paris, France; pickford@mnhn.fr

Pickford, M. 2015. Large ungulates from the basal Oligocene of Oman: 2 - Proboscidea [Grandes ungulados del Oligoceno basal de Oman: 2- Proboscidea]. Spanish Journal of Palaeontology, 30 (2), 209-222.

\begin{abstract}
Knowledge about the Palaeogene fossil record of the Arabian Peninsula has improved recently due to discoveries of Eocene - Oligocene age in Oman and Saudi Arabia. In the early 1990's primitive proboscideans were listed from Thaytiniti (Early Oligocene) in Oman, but the fossils were never described. Subsequently a proximal ulna from the Dhofar was attributed to an arsinoithere, but it is more likely to belong to a proboscidean than an embrithopod. Recently a lower jaw from the same region was described as the barytheriid Omanitherium. The present paper describes and illustrates the fossils collected at Thaytiniti and Taqah in 1992 and identifies them as the first known upper teeth of Omanitherium. The significance of these fossils for understanding the taxonomy and systematics of Omanitherium are discussed, and it is concluded that among all the known Proboscidea, this genus is most closely related to Arcanotherium from the Eo-Oligocene of Dor el Talha, Libya.
\end{abstract}

Keywords: Palaeogene, Oman, Proboscidea, Omanitherium, Arcanotherium.

\section{RESUMEN}

El conocimiento de registro fósil del Paleógeno de la península Arábiga ha mejorado recientemente por los descubrimientos de edad Eoceno-Oligoceno realizados en Omán y Arabia Saudí. A principios de los años 1990 proboscídeos primitivos fueron citados en Thaytiniti (Oligoceno temprano) en Omán, pero los fósiles nunca fueron descritos. Subsecuentemente una epífisis proximal de ulna procedente de Dhofar fue atribuida a un arsinoiterio, pero es más probable que pertenezca a un proboscídeo que a un embritópodo. Recientemente una mandíbula procedente de la misma región ha sido descrita como perteneciente al barytérido Omanitherium. El presente trabajo describe y figura los fósiles recolectados en 1992 en Thaytiniti y Taqah, identificando entre ellos los primeros dientes superiores de Omanitherium. El significado de estos fósiles para la comprensión de la taxonomía y sistemática de Omanitherium es discutido, y se concluye que entre todos los géneros conocidos de Proboscidea, es con Arcanotherium con el que se relaciona más estrechamente.

Palabras clave: Paleógeno, Omán, Proboscidea, Omanitherium, Arcanotherium. 


\section{INTRODUCTION}

Small proboscidean fossils found at Thaytiniti (Dhofar, Oman) (Fig. 1) were mentioned in papers by Thomas et al. $(1989,1992,1999)$ but the specimens have not been described. An upper premolar was also collected at Taqah, near Salalah, Oman, by the same expedition. Recently, AlSayigh et al. (2008) described a fossil ulna from the Aydim Formation, which they attributed to the Embrithopod Arsinoitherium. However, the dimensions of the specimen indicate that it is too small to belong to Arsinoitherium zitteli or Arsinoitherium andrewsi, so it belongs either to an undescribed small species of the genus, or more likely to a different small proboscidean. From the same region in Dhofar, a mandible with much of the dentition was described by Seiffert et al. (2012) and attributed to the new genus and species Omanitherium dhofarense and this could be the species to which the Aydim ulna belongs.

The aim of this paper is to describe the small proboscidean teeth found at Thaytiniti and Taqah in 1992 and to discuss their systematic positions. There are three upper teeth, part of a lower molar and a lower incisor from Thaytiniti and an upper premolar from Taqah. Previously described samples of Omanitherium do not preserve upper teeth, and the maxillary teeth of Arcanotherium from similar aged deposits in Libya, are poorly known (Delmer, 2009) which complicates the interpretation of the Omani sample, but the genus is evidently more closely related to Barytherium, Numidotherium and other small primitive lophodont proboscideans than it is to elephantiformes and deinotheres (sensu Sanders et al., 2004, 2010).

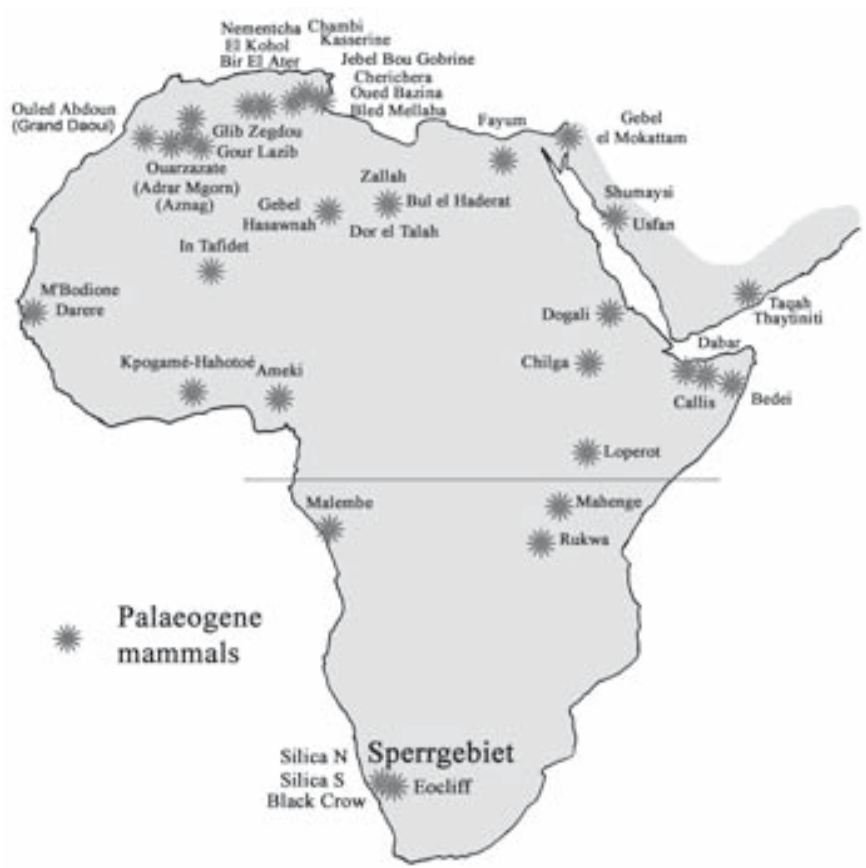

Figure 1. Palaeogene mammal localities of Afro-Arabia, showing the location of Thaytiniti and Taqah, Oman.

\section{MATERIAL AND METHODS}

Dental nomenclature (Figs 2, 3) is based on the system of Sanders et al. (2004). The fossils from Thaytiniti and Taqah are curated at the Oman Natural History Museum, Muscat (ONHM). Comparisons were made with fossils kept in the Sultan Qaboos University, Muscat (SQU), the Natural History Museum, London (NHMUK), the Muséum National d'Histoire Naturelle, Paris (MNHN) and the Naturhistorisches Museum Mainz (NHMM).

Measurements were made with sliding calipers to the nearest $0.1 \mathrm{~mm}$. Images were taken with a Sony Cybershot 14.1 megapixel camera and treated using Photoshop Elements 3 to increase contrast and remove unwanted background.

\section{SYSTEMATIC DESCRIPTION}

Order Proboscidea Illiger, 1811

Superfamily Barytherioidea Andrews, 1906

Genus Omanitherium Seiffert, Nasir, Al-Harthy, Groenke, Kraatz, Stevens \& Al-Sayigh, 2012

Diagnosis. Differs from early Eocene Numidotherium koholense (Mahboubi et al., 1986; Noubhani et al., $2008)$ in being relatively large $[\mathrm{m} / 1$ area (length $\times$ width) of $\sim 1,270 \mathrm{~mm}^{2}$ in $O$. dhofarense, compared to a mean (Noubhani et al., 2008) of $432 \mathrm{~mm}^{2}$ in $N$. koholense], and in combining the following features: a conical and tusk-like $\mathrm{i} / 2$; a relatively small $\mathrm{p} / 2$; a large metaconid on $\mathrm{p} / 3$ and entoconids on $\mathrm{p} / 3-\mathrm{p} / 4$; a more rectangular $\mathrm{p} / 4$ with no hypolophid, a relatively narrow talonid, and a centrally placed hypoconid; relatively broad and four-rooted lower molars that have relatively tall metaconids, cusps that show more basal inflation, trigonid and talonid cusps that are more equal in height, relatively distinct precingulids, no entocristids or premetacristids, and more basally inflated buccal margins; an $\mathrm{m} / 3$ with a relatively short hypoconulid lobe; a mediolaterally constricted symphyseal region, with a relatively long diastema between $\mathrm{i} / 2$ and $\mathrm{p} / 2$; and a relatively low coronoid process and more anteriorly positioned origin of the vertical ramus. Differs from Arcanotherium savagei (Court, 1995; Delmer, 2009) in exhibiting the following combination of features: a relatively small $\mathrm{p} / 2$; relatively tall $\mathrm{p} / 3-\mathrm{p} / 4$ hypoconids; no $\mathrm{p} / 4$ premetacristid; a $\mathrm{p} / 4$ with no hypolophid or premetacristid, a relatively narrow talonid, and a centrally placed hypoconid; relatively weak buccal cingulids; and relatively broad lower molars (particularly $\mathrm{m} / 2-\mathrm{m} / 3$ ) with more basally inflated cusps and buccal margins and no entocristid or premetacristid crests. Differs from 


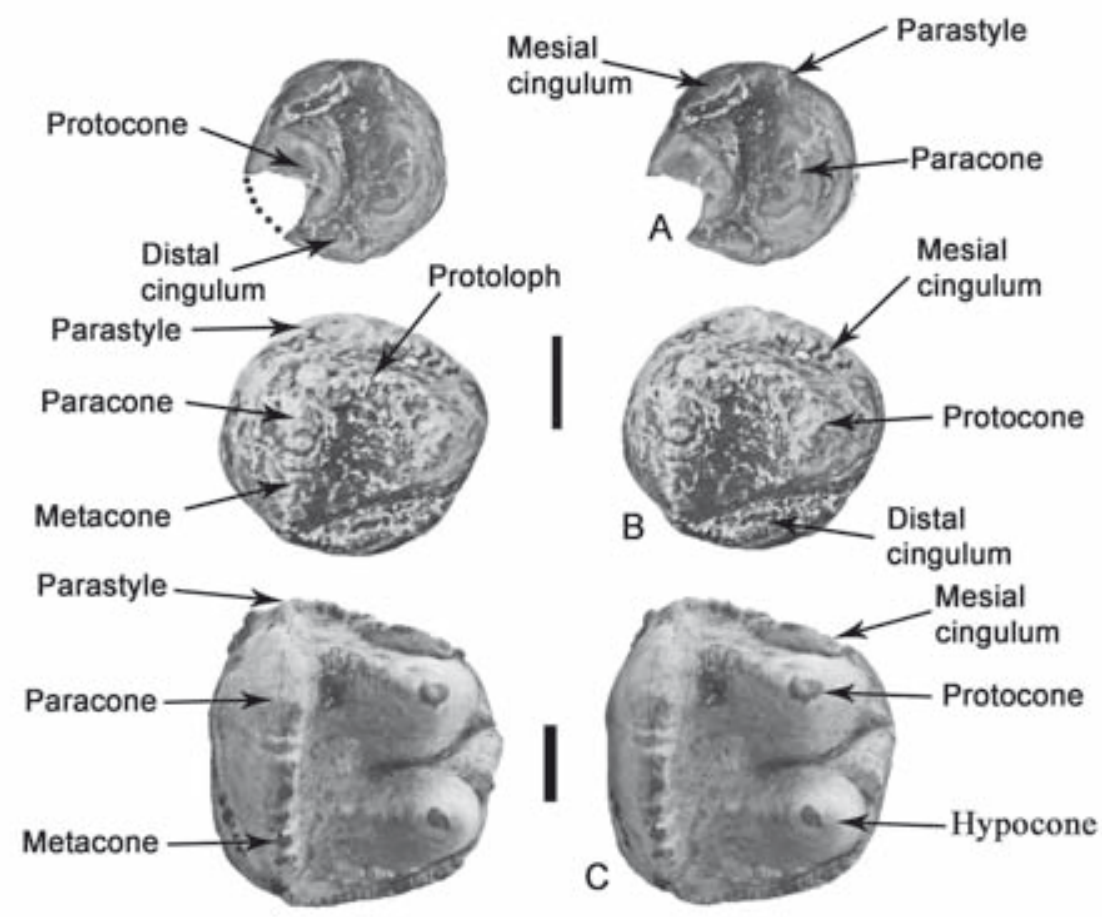

Figure 2. Dental nomenclature of upper premolars of primitive proboscideans and Deinotherium, adapted from Sanders et al. (2004). Stereo pairs of A) Omanitherium left P2/ (ONHM 1478-TH4), B) Omanitherium right P3/ (1478-TH3) and C) right P3/ of Deinotherium hobleyi (ONHM GB 33'14) from the Early Miocene of Ghaba, Oman. Scale bars: $10 \mathrm{~mm}$.
Barytherium grave (Andrews, 1906) in being much smaller $\left[\mathrm{m} / 2\right.$ area of $\sim 1,960 \mathrm{~mm}^{2}$ in $O$. dhofarense compared to $\sim 5,500 \mathrm{~mm}^{2}$ (Andrews, 1906) in B. grave from Fayum, Egypt], and in having a relatively small p/2; two-rooted $\mathrm{p} / 2-\mathrm{p} / 4 ; \mathrm{p} / 4$ with no premetacristid or hypolophid, a relatively narrow talonid, and a centrally placed hypoconid; and lower molars with more basally inflated buccal margins, and no entocristids or premetacristids. Differs from Moeritherium (Andrews, 1906; Matsumoto, 1923; Delmer et al., 2006) in having a conical and tusk-like i/2 that lacks serrations; a relatively small p/2; p/3-p/4 with distinct entoconids, no paraconids, and relatively large metaconids; a more rectangular $\mathrm{p} / 4$ with a protolophid, no premetacristid or hypolophid, a relatively narrow talonid, and a centrally placed hypoconid; lower molars with four roots, relatively small hypoconulids, no postentoconulids, weak buccal cingulids, more basally inflated buccal margins; and a significant "step" from the occlusal surfaces of the cheek teeth down to the dorsal aspect of the mandibular symphysis, which only extends back to $\mathrm{p} / 3$ (as opposed to p/4). Differs from early deinotheriids such as Prodeinotherium (Harris, 1973) in lacking a tritolophid on $\mathrm{m} / 1$ and a well-developed entoconid and hypolophid on $\mathrm{p} / 4$, and in having anteriorly directed lower incisors and no ventral curvature of the mandibular symphysis.

Type species. Omanitherium dhofarense Seiffert, Nasir, Al-Harthy, Groenke, Kraatz, Stevens \& Al-Sayigh, 2012

Omanitherium dhofarense

Seiffert, Nasir, Al-Harthy, Groenke, Kraatz, Stevens \& Al-Sayigh, 2012
Diagnosis. As for the genus.

Holotype. SQU-290, mandible with right i/2, p/3-m/2, and partial $\mathrm{m} / 3$, and left $\mathrm{p} / 4-\mathrm{m} / 2$ and erupting $\mathrm{m} / 3$.

Note on etymology. According to the International Code of Zoological Nomenclature (Ride et al., 1999) generic names which are neuter, such as names ending in -therium attached to a place name, should terminate in "-ense" rather than "-ensis" which is reserved for masculine and feminine generic names.

Additional material from the type locality. SQU-sans $\mathrm{n}^{\circ}$ - incisor fragment; SQU-sans $\mathrm{n}^{\circ}$ - right $\mathrm{p} / 4$.

Material from Thaytiniti. ONHM TH 4 - left P2/; ONHM TH 3 - right P3/; ONHM TH 5 - half left upper molar; ONHM TH 6 - left lower central incisor; ONHM Thaytiniti - distal half of left lower molar (probably m/1).

Material from Taqah. ONHM TQ 15 - left P4/.

Type locality. DPP-2010-1; UTM coordinates 39Q, $767804.80 \mathrm{~m} \mathrm{E}, 1878508.74 \mathrm{~m} \mathrm{~N}$.

Formation and age. Shizar Member of the Ashawq Formation, earliest Oligocene.

\section{Description.}

Shizar. The incisor fragment from Shizar (Figs 4A14A2) probably represents part of a lower central incisor on the grounds that it differs from the $i / 2$ in the holotype 

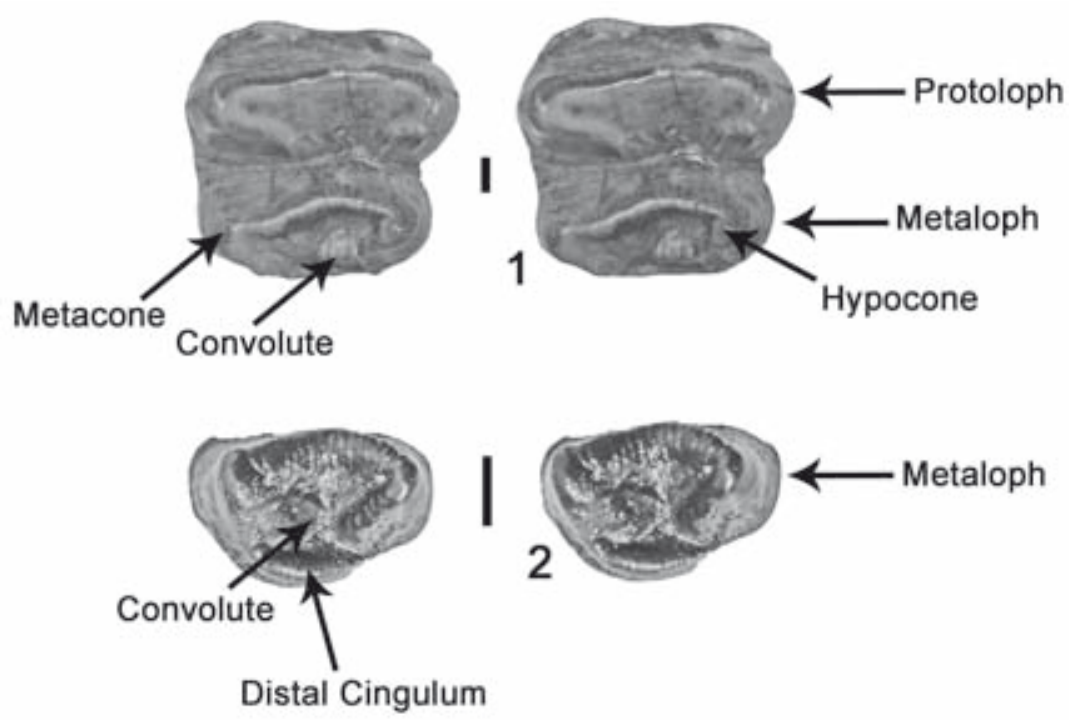

Figure 3. Dental nomenclature of upper molars of lophodont proboscideans, adapted from Sanders et al. (2004). Stereo occlusal view of 1) NHMM 1956-79, left M3/ of Deinotherium giganteum from GauWeinheim, Germany and 2) ONHM TH 5, Omanitherium dhofarense rear loph of left upper molar from Thaytiniti, Oman. Scale bars: $10 \mathrm{~mm}$. mandible both in dimensions and what little of the morphology that remains. If this is so then, Omanitherium was endowed with two lower incisors in each half of the mandible.

The undescribed p/4 (Fig. 4B) from Shizar has two bunodont cuspids anteriorly but the rear of the tooth is broken. The fragment resembles the $\mathrm{p} / 4$ in the holotype mandible and thereby indicates the presence of at least two individuals from the site.

The undescribed anterior fragment of right $\mathrm{m} / 3$ (Fig. 4C) from Shizar has the same preservation characters, unerupted appearance and dimensions as the $m / 3$ in the holotype mandible and probably represents the same individual.

Thaytiniti. The left lower central incisor (Fig. 5) from Thaytiniti (ONHM TH 6) is lightly worn. It is moderately spatulate in lingual outline with six undulations (weak serrations) along the distal margin. The tooth is only slightly narrower measured mesio-distally than the height measured from cervix to apex. There is a prominent flat wear facet near the apex of the lingual aspect of the tooth, indicating that there must have been an upper incisor in this species. In distal view the tooth is slightly concave lingually. The root is narrower than the crown in both labio-lingual and mesio-distal dimensions. This is not a hypsodont tooth.

The left P2/ (Figs 6A1-6A2) (ONHM TH 4) is almost unworn but is missing the rear of the protocone. It is comprised of two prominent cusps (protocone and paracone) on the buccal and lingual sides, separated by a deep antero-posteriorly oriented central valley. The parastyle is prominent at the anterior base of the paracone and it merges lingually with the broad, well-developed mesial cingulum. The lingual end of the mesial cingulum weakens in height and breadth near the base of the protocone. The lingual end of the distal cingulum is joined to the protocone, and slightly to the buccal side of the junction the cingulum swells, but does not form a distinct hypocone. The buccal end of the distal cingulum forms a tiny nub of enamel at the distal base of the paracone.

The right $\mathrm{P} 3 /$ (Figs 6B1-6B5) (ONHM TH 3) is a lophodont tooth comprised of two main cusps (paracone + metacone fused together and protocone) which are joined together by the preprotocrista which courses across the tooth to the front of the paracone, completely filling the mesial part of the central valley, but leaving the distal part of the valley open as a broad basin descending in altitude to the rear, the latter depression (the trigon basin) being bordered distally by the prominent, distal cingulum. The summit of the loph is subdivided by shallow indentations or mammelons which would wear away with slight use. The metacone is closely applied to the paracone and forms a wall-like ectoloph with a serrated apex, descending distally where it joins the buccal end of the distal cingulum. The lingual end of the distal cingulum is separated from the protocone by a cleft. The parastyle is weak (slightly worn in this specimen) and is close to the buccal end of the beaded mesial cingulum. The distal cingulum is separated from trigon basin by a narrow, but distinct bucco-lingual crevice. The distal cingulum rises and swells in its middle, but does not form a separate cusp.

The distal half of the left upper molar (Figs 6C16C2) (ONHM TH 5) is unworn, and shows a series of mammelons subdividing the metaloph into 17 serrations between the apices of the metacone and hypocone. The lingual and buccal walls of the crown are not vertical but slope steeply towards the cervix. The postmetacrista is broad with a serrated apex, and is directed disto-centrally, ending short of the swollen distal cingulum, from which it is separated by a deep cleft. The posthypocrista is a broad structure with a "rumpled" surface part of which descends distally towards the distal cingulum, and part of 

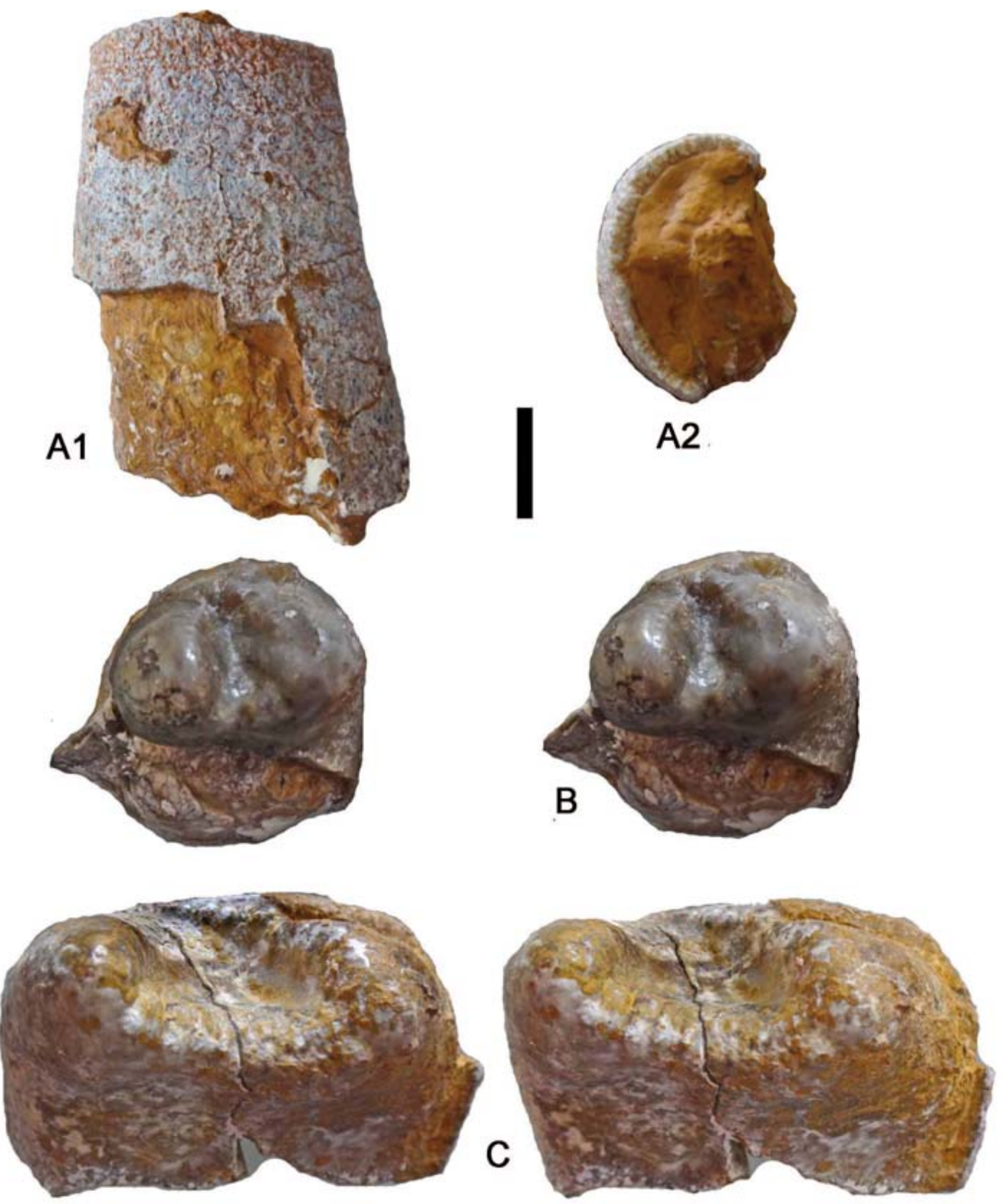

Figure 4. Omanitherium dhofarense tooth fragments from the type locality in the Shizar Member, Oman. A) SQU sans $\mathrm{n}^{\circ}$, fragment of lower central incisor, (A1) labial view, (A2) apical view. B) SQU sans nº, right p/4, stereo occlusal view; C) SQU-290, mesial lophid of right $\mathrm{m} / 3$, stereo occlusal view. Scale: $10 \mathrm{~mm}$. 

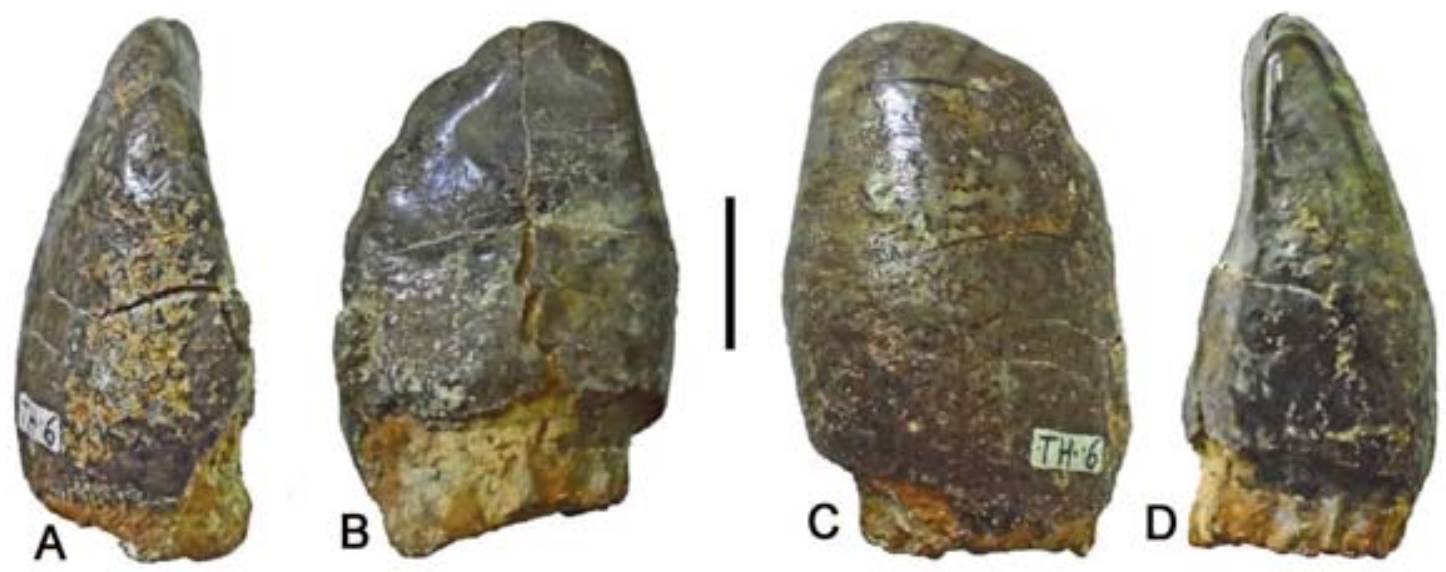

Figure 5. ONHM TH 6, left lower incisor from Thaytiniti, Oman, attributed to Omanitherium. A) distal, B) lingual, C) labial, D) mesial views. Scale: $10 \mathrm{~mm}$.
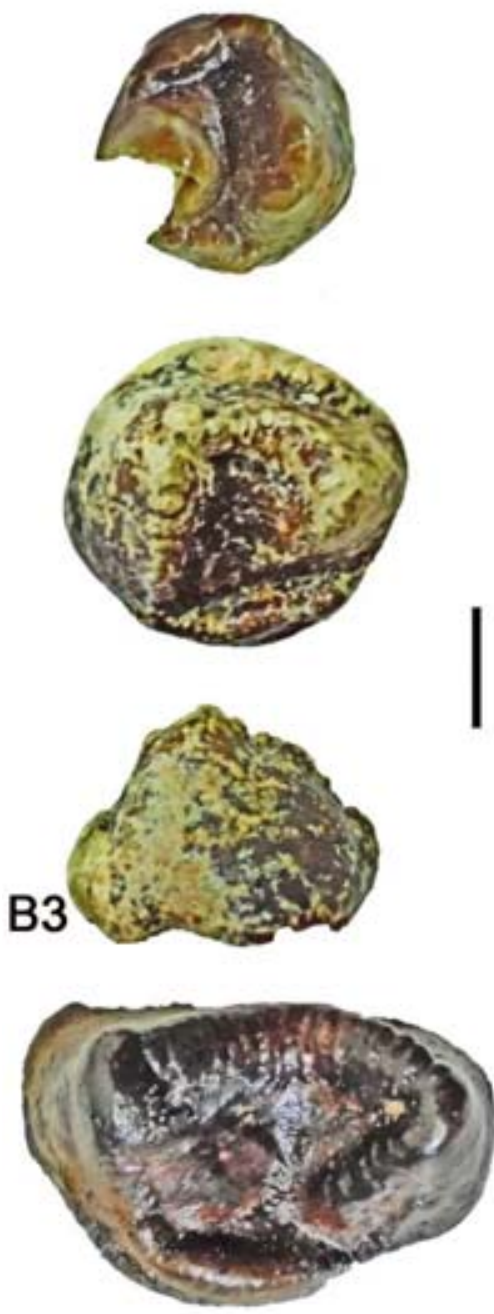
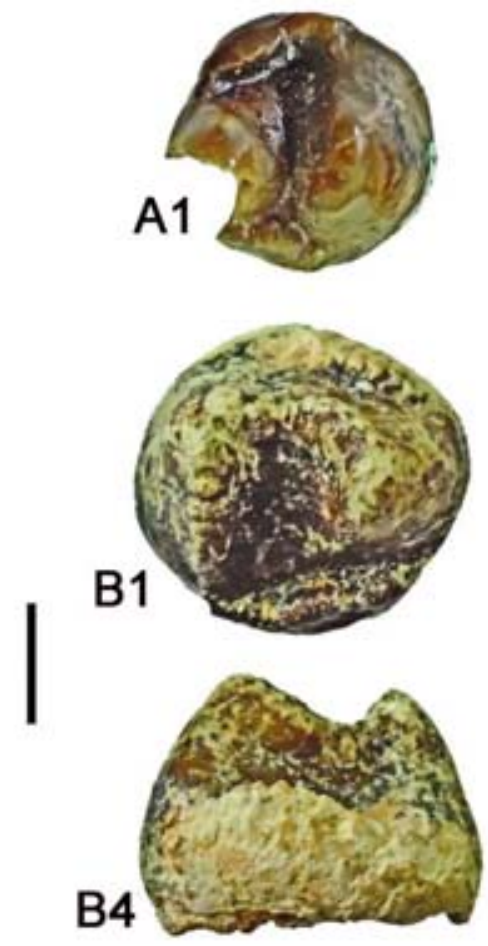

B2
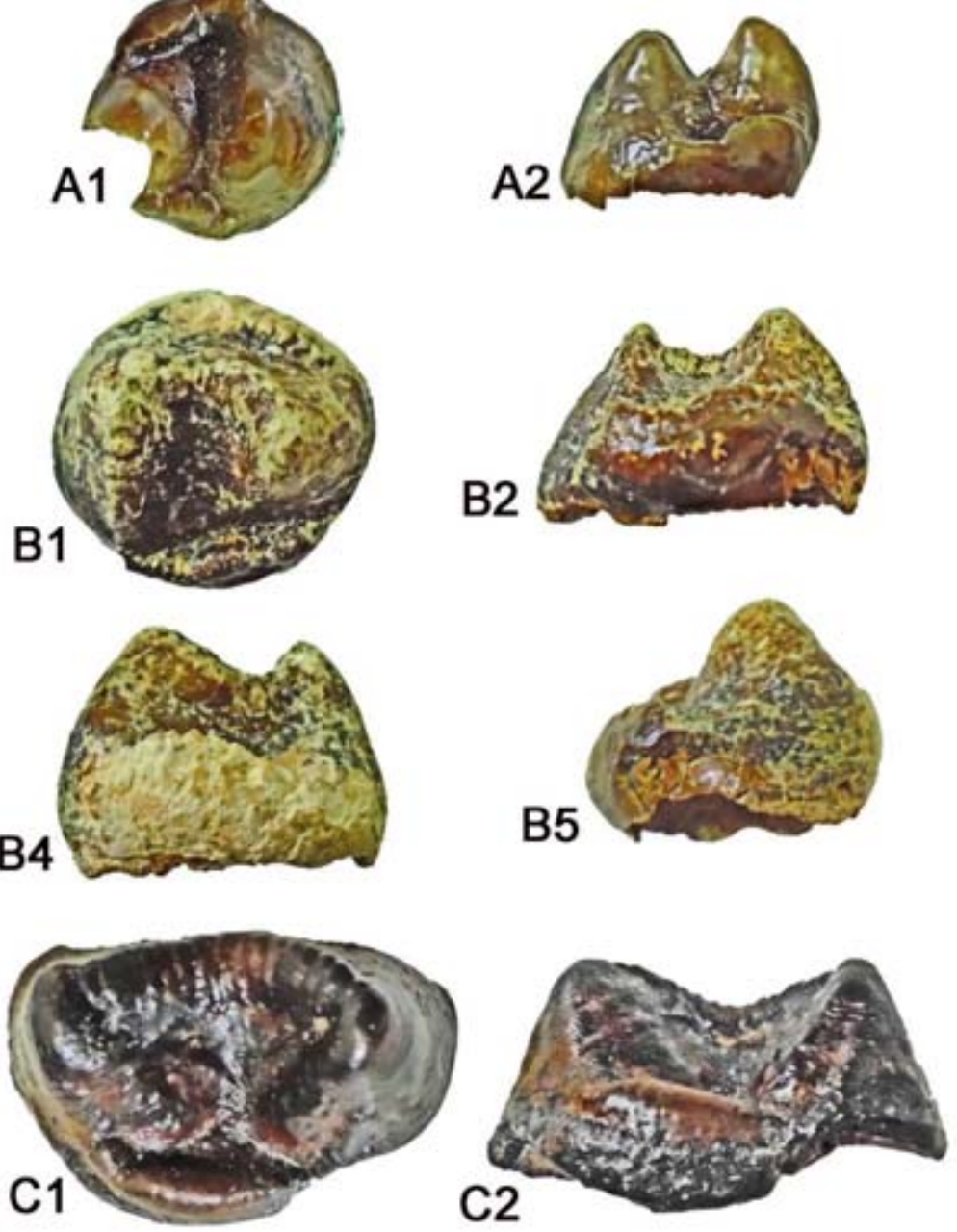

Figure 6. Upper teeth from Thaytiniti, Oman (Early Oligocene) attributed to Omanitherium. A) ONHM TH 4, left P2/, (A1) stereo occlusal view, (A2) mesial view. B) ONHM TH 3, right P3/, (B1) stereo occlusal view, (B2) distal, (B3) buccal, (B4) mesial, (B5) lingual views. C) ONHM TH 5, distal loph of left upper molar, (C1) stereo occlusal view, (C2) distal view. Scale: $10 \mathrm{~mm}$. 
which descends bucco-distally forming a knot of enamel that could be called a "convolute" (a structure found in deinothere upper molars; Tobien, 1988). The distal cingulum is swollen but low, and extends only about twothirds across the rear of the crown. There is no sign of a tritoloph between it and the rest of the crown.

ONHM Thaytiniti sans $n^{\circ}$ (Fig. 7) is the rear half of a left lower molar, probably $\mathrm{m} / 1$ based on its breadth dimension of $30.4 \mathrm{~mm}$. It shows the characteristic lophid with a beaded apical ridge comprising the hypoconid and metaconid, with a dip in the middle, and a prominent distal cingulum.
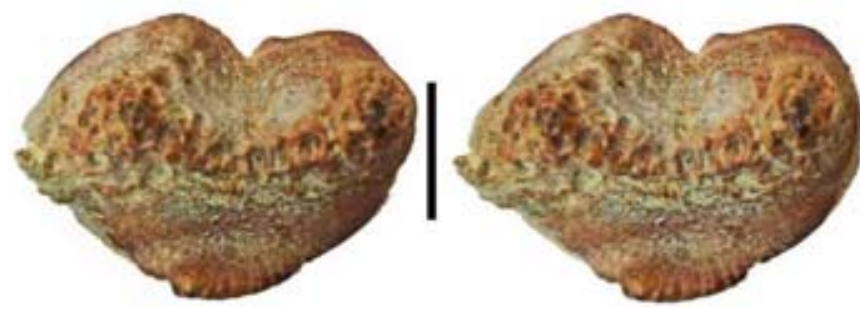

Figure 7. Omanitherium dhofarense, ONHM Thaytiniti sans $\mathrm{n}^{\circ}$, rear half of left $\mathrm{m} / 1$, stereo occlusal view. Scale: $10 \mathrm{~mm}$.

Taqah. The heavily worn upper premolar (Fig. 8) from Taqah (ONHM TQ 15) shows four principal cusps (protocone, paracone, metacone, hypocone) and well developed mesial and distal cingula (partly removed by interstitial wear). The root base is solidly constructed, with a large confluent root beneath the anterior loph and metacone, with a separate root beneath the metacone. The paracone and metacone are confluent at the base, but were separated apically and there is a prominent but low parastyle. The protocone and hypocone are more deeply worn and are larger than than the ectoloph cusps (paracone, metacone).

\subsection{New evidence concerning Arcanotherium savagei (Court, 1995)}

Examination of the type series of fossils of Arcanotherim savagei from Dor El Talha, Libya, stored in the Natural History Museum, London, led to the recognition of a part of an incisor root among the loose fragments of bone. This fragment makes excellent contact between the formerly isolated right central incisor crown, and the apex of the root in situ in the mandibular symphysis of the holotype. The importance of this discovery is fourfold. Firstly it confirms the fact that the incisors (M 82167a and 82167b) represent the same individual as the holotype of the species (Delmer, 2009). Secondly, it shows that the lower central incisors point anteriorly and slightly upwards in the symphysis, such that the worn apices of the crowns are just below the occlusal plane of the cheek teeth. Residual slight warping in the jaw and a small degree of play in the contacts between the crown, root fragment and root apex in the symphysis means that the exact orientation of the incisors is not possible to establish, but there can be no doubt that they are not flat-lying, nor do they show any signs of being down-curved as in deinotheres. Thirdly, the lingual surface of the central incisors is not parallel to the occlusal plane of the cheek teeth, but is angled such that the mesial edge of the crown is more ventral than the distal edge. Thus the lingual surfaces of the central incisors form an open v-shape, becoming more acutely v-shaped rootwards (Fig. 9). Fourthly, the wear on the apex of the central incisor reveals that there must have been upper central incisors in Arcanotherium, which occluded with the lower central incisors.

The lingual surface of the unerupted central incisor in the fragmentary symphysis, M 82183 (Delmer, 2009, fig. 3A) is vertically oriented (i.e., the lingual surfaces of the two central incisors are parallel to each other and are separated from each other by a thin layer of bone (the inter-alveolar lamina). From this, it is concluded that in Arcanotherium,
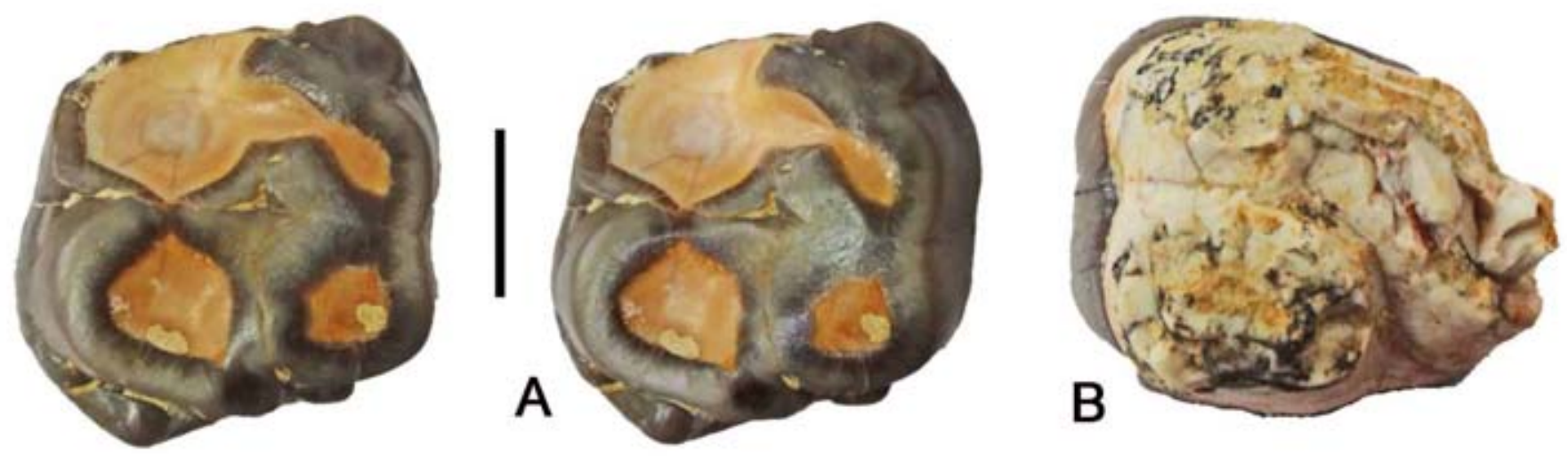

Figure 8. ONHM TQ 15, left P4/, Omanitherium dhofarense, from Taqah, Oman. A) Stereo occlusal view, B) radicular view. Scale: $10 \mathrm{~mm}$. 


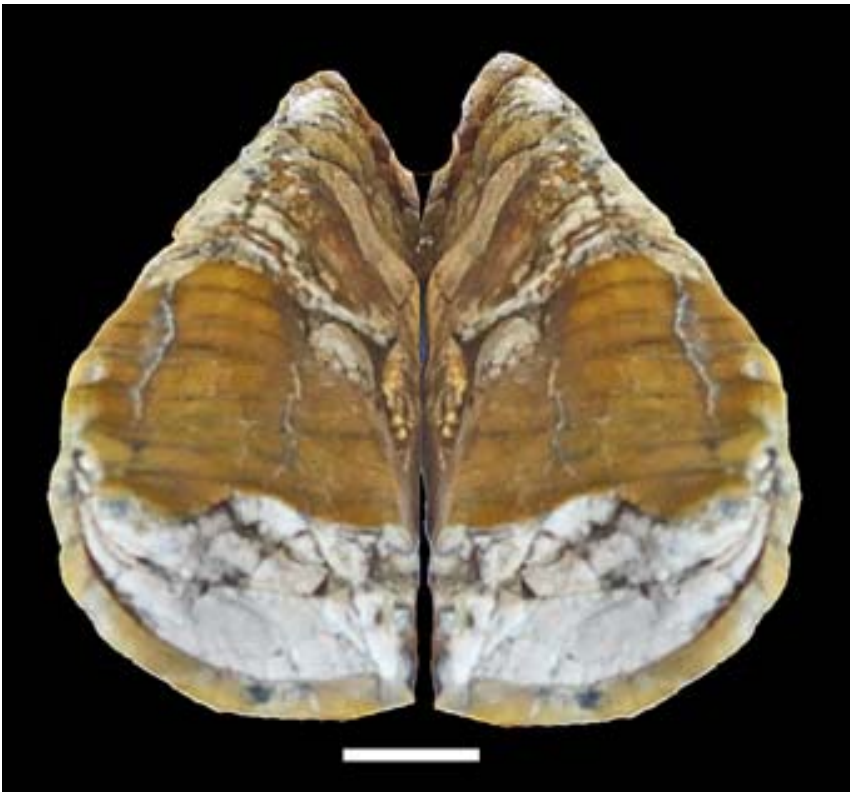

Figure 9. Anterior slightly oblique view of the left central incisor (with mirror image) of Arcanotherium savagei to show the open v-shaped angle formed by the lingual surface of the tooth. The V-shape becomes more marked towards the apices of the roots. Scale for anterior part of tooth: $10 \mathrm{~mm}$.

as the central incisors erupt, the crowns twist by about $70^{\circ}$ (clockwise in the right $\mathrm{i} / 1$, anticlockwise in the left one) much as in hyracoid lower central incisors, and come to lie in an open v-shaped configuration when fully erupted.

In his description of NHMUK M 82183, Delmer (2009) wrote that the root of the deciduous central incisor is medial to the root of the permanent central incisor. This is a lapsus, because the root is lateral to the central incisor, and is located medial and somewhat ventral to the alveolus of the permanent $\mathrm{i} / 2$. This observation may modify the argument concerning incisor homologies in Arcanotherium, deinotheres and elephantiformes

In his reconstruction of the mandible of Arcanotherium (Delmer, 2009, fig. 1b) the central incisors are shown projecting somewhat further out from the symphysis than is likely to be the case. The crown-root margin probably ought to coincide with the alveolar margin. The second incisors are positioned somewhat lateral and dorsal to the central incisors, and the alveoli penetrate more deeply into the symphysis than those of the i/1s (Fig. 10).

The upper molar fragment (Fig. 11) of Omanitherium from Thaytiniti (ONHM TH 5) resembles a specimen from Dor El Talha, NHMUK M 82398 (Court, 1995; Delmer, 2009). Particular points or similarity are the marked buccal and lingual flare of the loph (narrow apically, broader basally) the development of mammelons along the crest of the loph, the well-developed, swollen posthypocrista, weaker postmetacrista, and the presence of an incipient convolute, marked by small enamel pustules. Most of the distal cingulum has broken off the specimen, as has much of the postmetacrista. The crest of the metaloph dips centrally in both Arcanotherium and Omanitherium.

\subsection{Comparison of incisors of Omanitherium and Arcanotherium}

The holotype mandible (Fig. 12) of Omanitherium dhofarense was reconstructed to show a single pair of incisors separated from each other by a broad gap (Seiffert et al., 2012). The incisors were interpreted to represent the $\mathrm{i} / 2 \mathrm{~s}$. The recognition of a lower central incisor at Thaytiniti (mentioned briefly by Seiffert et al., 2012), which is compatible in dimensions to what would be expected for Omanitherium, modifies the reconstruction. The Thaytiniti central incisor resembles those of Arcanotherium in several respects. The serrations along the distal margin of the Thaytiniti crown are less well marked than in the unerupted incisor in M. 82183 (partly due to the more advanced stage of wear in the Thaytiniti tooth) but are more marked than those in the holotype jaw of Arcanotherium savagei (M 82176) which are more heavily worn.

The space between the lateral incisors in Omanitherium is large enough to accommodate the Thaytiniti tooth if it is oriented in the same way as the central incisor in Arcanotherium (i.e., with the lingual surface in an open $\mathrm{v}$-shaped configuration). From this it is concluded that Omanitherium, like Arcanotherium, probably possessed two lower incisors.

A significant difference between the teeth of Omanitherium and Arcanotherium concerns their breadth / length proportions (Table 1), as already noted by Seiffert et al. (2012). The cheek teeth of Omanitherium are consistently broader relative to length than are those of Arcanotherium (Fig. 13). However, the lengths of the cheek teeth in the two taxa are very close, indicating that they probably had rather similar body dimensions.

\subsection{Relationships of Omanitherium to Chilgatherium and Deinotherium}

The P3/ of Omanitherium described herein presages the morphology of this tooth in Deinotherium. The paracone and metacone form a complete ectoloph (Fig. 6B) which is remarkably similar structurally in the two genera, as is the form of the protoloph linking the protocone to the ectoloph with a dip in the protoloph close to the ectoloph. The P3/ of Omanitherium lacks a hypocone, but the distal cingulum is enlarged and swollen in the middle, morphology possibly heralding the development of a hypocone (Fig. 6B). From this resemblance in premolar morphology, it is likely that Omanitherium and Deinotherium are phylogenetically related to each other. 


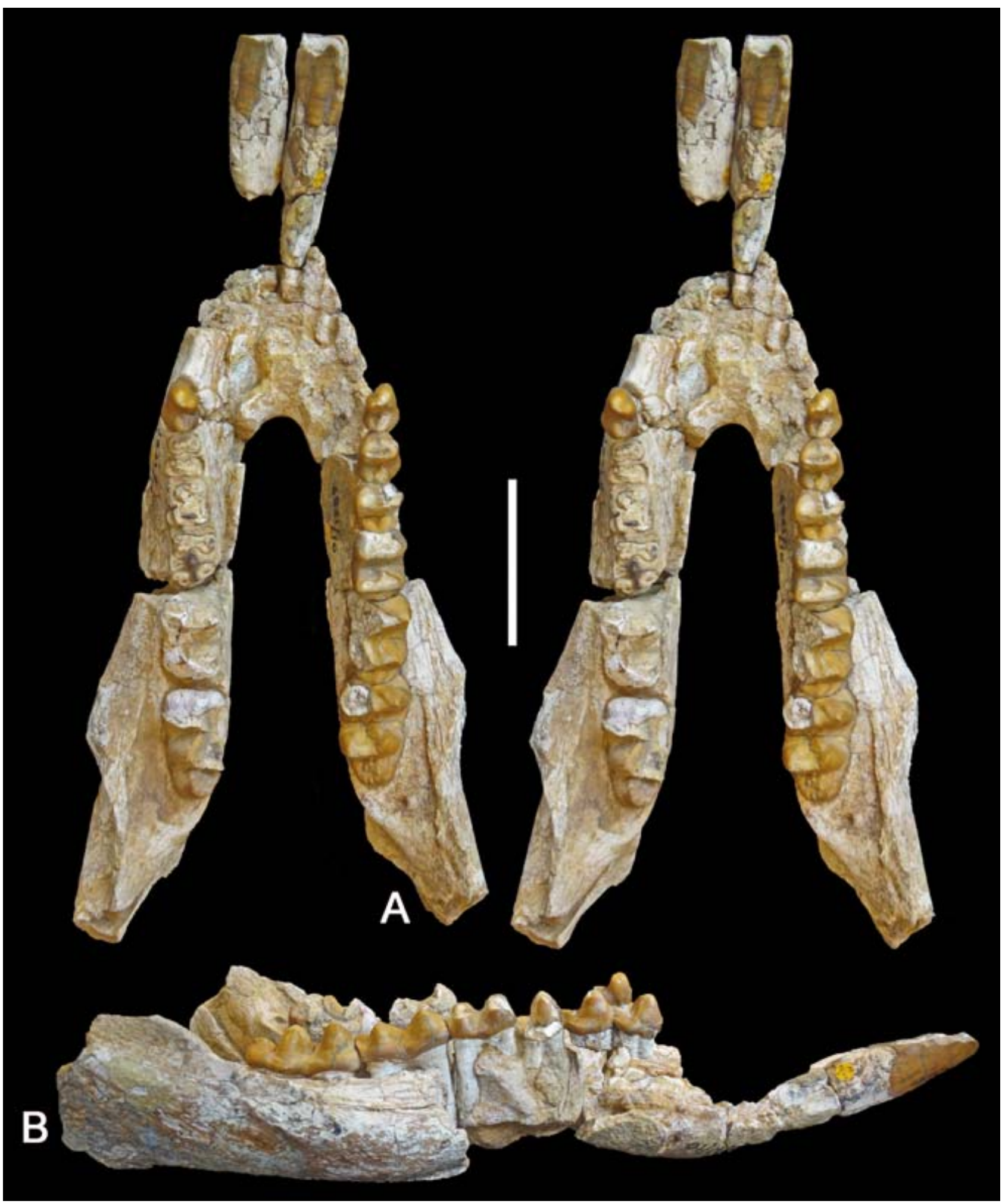

Figure 10. Stereo occlusal (A) and right lateral (B) views of the holotype mandible of Arcanotherium savagei from Dor El Talha, Libya, showing the central incisors articulated with the symphysis and bodies of the mandible. Scale: $10 \mathrm{~cm}$.

It is pertinent to point out that the upper premolars from Chilga, Ethiopia, attributed to Chilgatherium by Sanders et al. (2004) are not lophodont, but bunodont with wellindividualised cusplets. The association of such bunodont premolars with lophodont molars called for comment by Delmer (2009) and it is probable that the premolars do not belong to Chilgatherium, but to another proboscidean with bunodont or bunolophodont molars. 

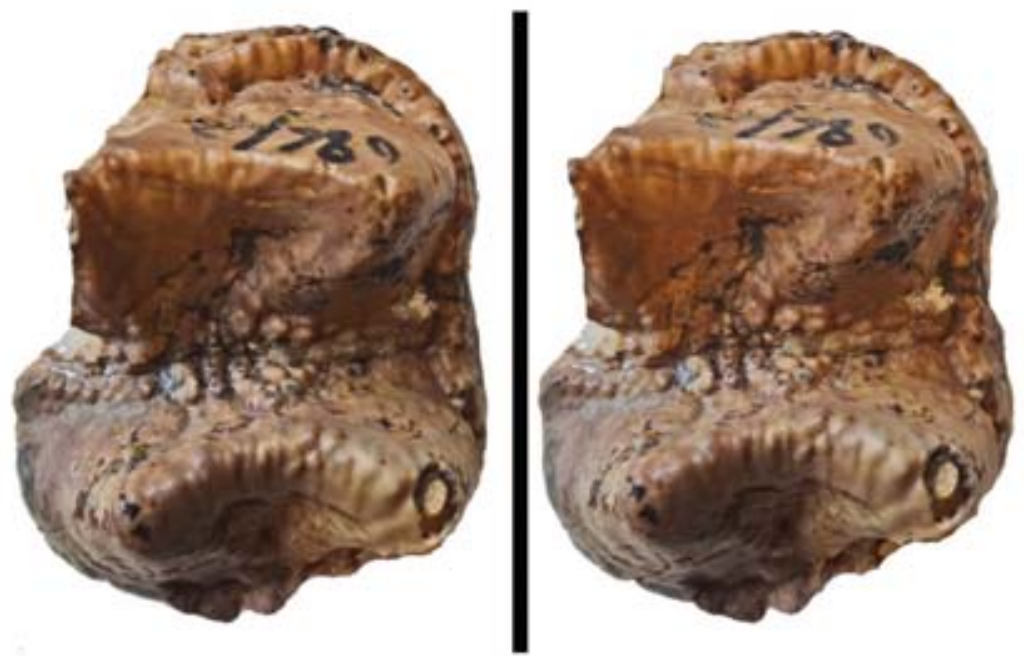

Figure 11. NHMUK M 82398, stereo occlusal view of right upper molar of Arcanotherium savagei from Dor El Talha, Libya. Scale: $5 \mathrm{~cm}$. Note that the postmetacrista and most of the distal cingulum have broken away. (Compare with Omanitherium from Thaytiniti, Fig. 6C).

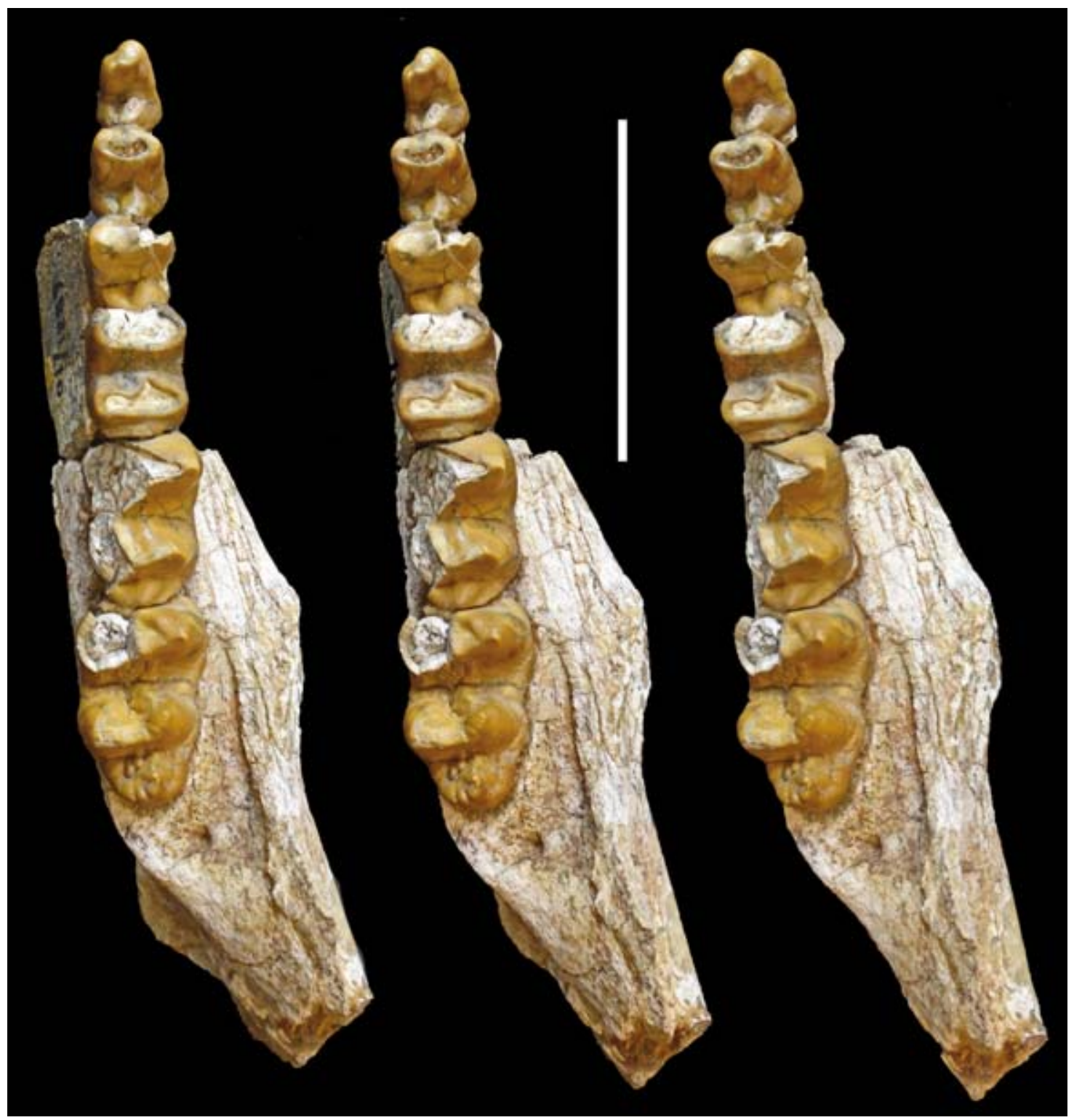

Figure 12. NHMUK M 82163, stereo triplet of the right mandible and cheek teeth (p/2-m/3) part of the holotype of Arcanotherium savagei from Dor El Talha, Libya. Scale: $10 \mathrm{~cm}$. 
Table 1. Measurements (in mm) of the teeth of Arcanotherium and Omanitherium (own = Author's own measurements with year of acquisition; frag $=$ fragment, $\mathrm{lt}=\mathrm{left}, \mathrm{rt}=$ right, $0=$ no measurement possible) (for teeth, lower case denotes lower teeth, upper case denotes upper teeth, forward slash denotes the occlusal surface, the number is below the slash for lower teeth, above it for upper teeth, * meristic position not known).

\begin{tabular}{|c|c|c|c|c|c|c|}
\hline Catalogue & Tooth & Length & Breadth & Locality & Genus & $\begin{array}{c}\text { Data source and } \\
\text { comments }\end{array}$ \\
\hline NHMUK M 82167a & $\mathrm{i} / 1 \mathrm{lt}$ & 27.3 & 25.5 & Dor El Talha, Libya & Arcanotherium & own, 2014 \\
\hline NHMUK M $82167 b$ & $\mathrm{i} / 1 \mathrm{rt}$ & 27.3 & 27 & Dor El Talha, Libya & Arcanotherium & own, 2014 \\
\hline NHMUK M 82165 & $\mathrm{~m} / 1 \mathrm{lt}$ & 37.8 & 27 & Dor El Talha, Libya & Arcanotherium & own, 2014 \\
\hline NHMUK M 82163 & $\mathrm{~m} / 1 \mathrm{rt}$ & 35 & 27.2 & Dor El Talha, Libya & Arcanotherium & own, 2014 \\
\hline NHMUK M 82165 & $\mathrm{~m} / 1 \mathrm{rt}$ & 36.6 & 26.8 & Dor El Talha, Libya & Arcanotherium & own, 2014 \\
\hline SQU-290 & $\mathrm{m} / 1 \mathrm{lt}$ & 39.6 & 32.2 & Shizar, Oman & Omanitherium & $\begin{array}{l}\text { Seiffert et al., 2012; } \\
\quad 39,5 \times 32,15\end{array}$ \\
\hline SQU-290 & $\mathrm{m} / 1 \mathrm{rt}$ & 39 & 32 & Shizar, Oman & Omanitherium & $\begin{array}{c}\text { Seiffert et al., } 2012 ; \\
39.85 \times 31.9\end{array}$ \\
\hline NHMUK M 82165 & $\mathrm{~m} / 2 \mathrm{lt}$ & 47.3 & 33 & Dor E1 Talha, Libya & Arcanotherium & own, 2014 \\
\hline NHMUK M 82163 & $\mathrm{~m} / 2 \mathrm{rt}$ & 46 & 0 & Dor El Talha, Libya & Arcanotherium & own, 2014 \\
\hline NHMUK M 82165 & $\mathrm{~m} / 2 \mathrm{rt}$ & 48 & 33.5 & Dor El Talha, Libya & Arcanotherium & own, 2014 \\
\hline SQU-290 & $\mathrm{m} / 2 \mathrm{lt}$ & 48 & 39.2 & Shizar, Oman & Omanitherium & $\begin{array}{l}\text { Seiffert et al., } 2012 \text {; } \\
\quad 48.6 \text { × } 39.3\end{array}$ \\
\hline SQU-290 & $\mathrm{m} / 2 \mathrm{rt}$ & 48 & 39 & Shizar, Oman & Omanitherium & $\begin{array}{l}\text { Seiffert et al., 2012; } \\
\quad 50.75 \text { x } 39.65\end{array}$ \\
\hline NHMUK M 82165 & $\mathrm{~m} / 3 \mathrm{lt}$ & 60 & 36.3 & Dor El Talha, Libya & Arcanotherium & own, 2014 \\
\hline NHMUK M 82163 & $\mathrm{~m} / 3 \mathrm{rt}$ & 55.3 & 35.5 & Dor El Talha, Libya & Arcanotherium & own, 2014 \\
\hline NHMUK M 82169 & $\mathrm{~m} / 3 \mathrm{rt}$ & 63 & 39.4 & Dor El Talha, Libya & Arcanotherium & own, 2014 \\
\hline SQU-290 & $\mathrm{m} / 3 \mathrm{lt}$ & 61 & 43.6 & Shizar, Oman & Omanitherium & $\begin{array}{l}\text { Seiffert et al., 2012; } \\
\quad 61.7 \text { x } 43.6\end{array}$ \\
\hline NHMUK M 82712 & $\mathrm{M} 1 / \mathrm{rt}$ & 38 & 36.3 & Dor El Talha, Libya & Arcanotherium & own, 2014 \\
\hline NHMUK M 82398 & $\mathrm{M} 2 / \mathrm{rt}$ & 46.3 & 38.6 & Dor El Talha, Libya & Arcanotherium & own, 2014 \\
\hline NHMUK M 82163 & $\mathrm{p} / 2 \mathrm{rt}$ & 23.9 & 18.1 & Dor El Talha, Libya & Arcanotherium & own, 2014 \\
\hline NHMUK M 82165 & $\mathrm{p} / 2 \mathrm{rt}$ & 23.8 & 18 & Dor El Talha, Libya & Arcanotherium & own, 2014 \\
\hline NHMUK M 82163 & $\mathrm{p} / 3 \mathrm{rt}$ & 25.4 & 21.8 & Dor El Talha, Libya & Arcanotherium & own, 2014 \\
\hline NHMUK M 82165 & $\mathrm{p} / 3 \mathrm{rt}$ & 25.6 & 21.1 & Dor El Talha, Libya & Arcanotherium & own, 2014 \\
\hline SQU-290 & $\mathrm{p} / 3 \mathrm{rt}$ & 22.6 & 21 & Shizar, Oman & Omanitherium & $\begin{array}{l}\text { Seiffert et al., 2012; } \\
\qquad 22,4 \text { x } 20,85\end{array}$ \\
\hline NHMUK M 82165 & $\mathrm{p} / 4 \mathrm{lt}$ & 27.7 & 23.6 & Dor El Talha, Libya & Arcanotherium & own, 2014 \\
\hline NHMUK M 82163 & $\mathrm{p} / 4 \mathrm{rt}$ & 27 & 25 & Dor El Talha, Libya & Arcanotherium & own, 2014 \\
\hline NHMUK M 82165 & $\mathrm{p} / 4 \mathrm{rt}$ & 27.7 & 24 & Dor El Talha, Libya & Arcanotherium & own, 2014 \\
\hline SQU-290 & $\mathrm{p} / 4$ lt & 26.8 & 25 & Shizar, Oman & Omanitherium & $\begin{array}{l}\text { Seiffert et al., 2012; } \\
\qquad 26,4 \text { × } 24,8\end{array}$ \\
\hline SQU-290 & $\mathrm{p} / 4 \mathrm{rt}$ & 27 & 25 & Shizar, Oman & Omanitherium & $\begin{array}{l}\text { Seiffert et al., 2012; } \\
25,6 \text { × } 24,9\end{array}$ \\
\hline ONHM 1478-TH4 & $\mathrm{P} 2 / \mathrm{rt}$ & 22 & 23 & Thaytiniti, Oman & Omanitherium & own, 2013 \\
\hline ONHM 1478-TH3 & $\mathrm{P} 3 / \mathrm{rt}$ & 26 & 29 & Thaytiniti, Oman & Omanitherium & own, 2013 \\
\hline ONHM 1478-TH6 & $\mathrm{i} / 1 \mathrm{lt}$ & 32 & 22.2 & Thaytiniti, Oman & Omanitherium & own, 2013 \\
\hline ONHM 1478-TH5 & $\begin{array}{l}\mathrm{M}^{* /} \\
\text { loph }\end{array}$ & 0 & 39.9 & Thaytiniti, Oman & Omanitherium & own, 2013 \\
\hline ONHM TQ 15 & $\mathrm{P} 4 / \mathrm{lt}$ & 25 & 25.6 & Taqah, Oman & Omanitherium & own, 2014 \\
\hline ONHM Thaytiniti & $\begin{array}{l}\mathrm{m} \\
\text { frag } 1 \mathrm{t}\end{array}$ & 0 & 30.4 & Thaytiniti, Oman & Omanitherium & own, 2014 \\
\hline SQU-sans n ${ }^{\circ}$ & $\mathrm{p} / 4 \mathrm{rt}$ & 0 & 23.9 & Thaytiniti, Oman & Omanitherium & own, 2014 \\
\hline SQU-290 & $\mathrm{m} / 3 \mathrm{rt}$ & 0 & 44.3 & Thaytiniti, Oman & Omanitherium & own, 2014 \\
\hline
\end{tabular}




\section{DISCUSSION}

A major difficulty encountered when interpreting the restricted sample of lophodont Oligocene proboscidean teeth from Oman is due to the fact that the Eo-Oligocene fossil record of upper teeth of this group is exceedingly poor. Delmer (2009) for example, described only three upper molars of Arcanotherium savagei, all of which were broken or worn. Seiffert et al. (2012) described no upper teeth of Omanitherium dhofarense. This is one of the reasons why the Thaytiniti and Taqah fossils are important, despite their restricted nature, because four of the teeth are from the upper dental series. A second important point about the Omani specimens is that the central lower incisor is preserved and can be compared with that of Arcanotherium. The same tooth of Omanitherium has not previously been observed. Indeed, Seiffert et al. (2012) concluded that Omanitherium might not have possessed lower central incisors. However, the symphysis of the holotype is not well preserved, and there is in fact sufficient space for a pair of central incisors between the two second incisors, and in the Sultan Qaboos University collection there is a fragment of a lower incisor that possibly represents a lower central incisor. In Arcanotherium, the roots of the two central incisors are short, do not penetrate as deeply into the symphysis as those of the $\mathrm{i} / 2$, and the long axis of their section is almost vertically oriented (Delmer, 2009). If the same alveolar relationship occurred in Omanitherium dhofarense, then the Thaytiniti tooth could readily fit between the second incisors of this species.

The lower incisor from Thaytiniti is well preserved and the prominent flat wear facet on the lingual aspect of the crown reveals that the species must have had an upper incisor which occluded with the lower central one. The presence of upper incisors is known in Numidotherium (Mahboubi et al., 1986; Noubhani et al., 2008) and Barytherium (Sanders et al., 2010) but they are absent in deinotheres.

The P2/ from Thaytiniti is bicuspid and non-lophodont, in accordance with the bunodont morphology of the lower anterior premolars of Arcanotherium and Omanitherium. The P3/ from Thaytiniti, in contrast is lophodont and also has the paracone and metacone fused together to form an ectoloph as in deinotheres, but the protocone is not accompanied by a hypocone. The worn P4/ of Omanitherium found at Taqah shows an underlying bunodont morphology, but the crown is deeply worn rendering it impossible to know whether it showed any lophodont tendencies near the cusp apices.

The distal half of the upper molar from Thaytiniti is remarkably similar to the M2/ of Arcanotherium (the only well preserved and unworn specimen available for comparison) and its morphology presages that observed in deinotheres, especially the knot-like mass of enamel on the distal surface of the metaloph which resembles the convolute of deinothere upper second and third molars (Tobien, 1988).

The lower incisor from Thaytiniti is close to that of Arcanotherium savagei being slightly less tall, but showing similar undulations along the distal margin of the crown, and similar rooted morphology, closed off at maturity in Arcanotherium. The Thaytiniti incisor has thick enamel all round the apex, just like that of the second incisor of the holotype of Omanitherium dhofarense (Seiffert et al., 2012) unlike Deinotherium which has a thin enamel cap which soon wears away with use and in which the root is hypsorhizic. The lower incisors of Arcanotherium and Omanitherium differ markedly from those of Barytherium, in which the enamel covers only the labial surface and part of the mesial and distal sides, leaving the lingual side and half the mesial and distal sides enamel-free.

From all this it is concluded that Omanitherium is phylogenetically closer to Arcanotherium and Numidotherium than it is to Barytherium or Deinotherium. A question remains to be researched once better material is forthcoming. Could Omanitherium and Arcanotherium be synonyms? They share a large number of dental and mandibular similarities, and the supposed differences enumerated by Seiffert et al. (2012) may be more apparent than real or related to the juvenile status of the holotype of Omanitherium dhofarense compared to the fully adult condition of the holotype of Arcanotherium savagei. Among the latter possibility features the position of the rear of the symphysis, further distally in Omanitherium than in Arcanotherium. The following features were listed by Seiffert et al. (2012) "the molars and premolars of Omanitherium are morphologically intermediate between those of Arcanotherium and Barytherium from northern Africa, but its specialized lower incisors are unlike those of other known Paleogene proboscideans in being greatly enlarged, high-crowned, conical, and tusk-like". The Thaytiniti lower central incisor throws doubt on the validity of this supposed difference between Arcanotherium and Omanitherium, although it reinforces the differences between Barytherium on the one hand and Omanitherium and Arcanotherium on the other. This is because the lower incisors of Barytherium are considerably taller and more slender than those of the other two genera, but more importantly, enamel covers only the labial and parts of the mesial and distal surfaces of lower incisors of Barytherium, the lingual surface being enamel-free.

Furthermore Seiffert et al. (2012) wrote in the diagnosis of the genus that Omanitherium "differs from Arcanotherium savagei (Court, 1995; Delmer, 2009) in exhibiting the following combination of features: a relatively small $p / 2$; relatively tall $p / 3-p / 4$ hypoconids; no $\mathrm{p} / 4$ premetacristid; a p/4 with no hypolophid or premetacristid, a relatively narrow talonid, and a centrally placed hypoconid; relatively weak buccal cingulids; and 
relatively broad lower molars (particularly $m / 2-m / 3$ ) with more basally inflated cusps and buccal margins and no entocristid or premetacristid crests". These differences between the lower cheek teeth of Omanitherium and Arcanotherium and the broader lower cheek teeth of Omanitherium, indicate the presence of two distinct, but closely related genera. The hypoconids of the premolars in Arcanotherium are relatively tall and centrally placed and have weak or non-existant buccal cingulids just as in Omanitherium. The lower molars of Omanitherium dhofarense are broader than those of Arcanotherium savagei, but the measurements of the premolars and molars of these two forms reveal that overall they were similar in dimensions. A marked similarity between these two forms is the presence of a slightly raised central swelling (hypoconulid) in the midline of the distal cingulids of the premolars and molars, and the presence, in unworn teeth, of mammelons along the apices of the lophids, which soon wear away with abrasion.

Postcranial evidence is of pertinence for throwing light on the relationships of these genera. Arcanotherium has an ulna (Delmer, 2009) which looks similar in overall morphology and dimensions to the supposed arsinoithere ulna from the Aydim Formation, Dhofar (Al-Sayigh et al., 2008) which, on the basis of its dimensions and morphology, is more likely to represent Omanitherium than Arsinoitherium. Thus not only do Omanitherium and Arcanotherium share some features of their dental morphology, they also share some postcranial similarities.

\section{ACKNOWLEDGEMENTS}

The Oman Ministry of Commerce and Industry is thanked for authorising the research, and the Oman Natural History Museum and the Sultan Qaboos University, Muscat, the Natural History Museum, London, the Muséum National d'Histoire Naturelle, Paris, and the Naturhistorisches Museum, Mainz, for access to fossils in their care. The proboscidean fossils were collected during expeditions to Dhofar led by H. Thomas in the early 1990's, financed by the Collège de France, the French BRGM and the CNRS. Funding from Sorbonne Universités - CR2P, MNHN, CNRS, UPMC - Paris VI, during the 2013 and 2014 surveys in Oman is gratefully acknowledged. Funding was also provided by the Oman Geological Society (Dr M. AlKindi). I thank the two reviewers, Drs Seiffert and Ros, for the thorough comments and suggestions.

\section{REFERENCES}

Al-Sayigh, A.R., Nasir, S., Schulp, A.S. \& Stevens. N.J. 2008. The first described Arsinoitherium from the Upper Eocene Aydim Formation of Oman: Biogeographic implications. Palaeoworld, 17, 41-46.

Andrews, C.W. 1906. A Descriptive Catalogue of the Tertiary Vertebrata of the Fayum, Egypt. British Museum of Natural History, London.

Court, N. 1995. A new species of Numidotherium (Mammalia, Proboscidea) from the Eocene of Libya and the early phylogeny of the Proboscidea. Journal of Vertebrate Paleontology, 15 (3), 650-671.

Delmer, C. 2009. Reassessment of the generic attribution of Numidotherium savagei and the homologues of lower incisors in proboscideans. Acta Palaeontologica Polonica, 54 (4), 561-580.

Delmer, C., Mahboubi, M., Tabuce, R. \& Tassy, P. 2006. A new species of Moeritherium (Proboscidea, Mammalia) from the Eocene of Algeria: New perspectives on the ancestral morphotype of the genus. Palaeontology, 49, 421-434.

Harris, J.M. 1973. Prodeinotherium from Gebel Zelten, Libya. Bulletin of the British Museum (Natural History) Geology, 23, 283-348.

Mahboubi, M., Ameur, R., Crochet, J.Y. \& Jaeger, J.-J. 1986. El Kohol (Saharan Atlas, Algeria): A new Eocene mammal locality in Northwestern Africa. Palaeontographica Abteilung A, 192, 15-49.

Matsumoto, H. 1923. A contribution to the knowledge of Moeritherium. Bulletin of the American Museum of Natural History, 49 (4), 97-140.

Noubhani, A., Hautier, L., Jaeger, J.-J., Mahboubi, M. \& Tabuce, R. 2008. Variabilité dentaire et crânienne de Numidotherium koholense (Mammalia, Proboscidea) from El Kohol, Eocene, Algeria. Geobios, 41, 515-531.

Ride, W.D.L., Cogger, H.G., Dupuis, C., Kraus, C., Minelli, A., Thompson, F.C. \& Tubbs, P.K. 1999. International Code of Zoological Nomenclature, 4th Edition. International Trust for Zoological Nomenclature, The Natural History Museum, London.

Sanders, W.J., Gheerbrant, E., Harris, J.M., Saegusa, H. \& Delmer, C. 2010. Proboscidea. In: Cenozoic Mammals of Africa (eds. Werdelin, L. \& Sanders, W.J.). University of California Press, Berkeley, Los Angeles, London, 161-251.

Sanders, W.J., Kappelman, J. \& Rasmussen D.T. 2004. New large-bodied mammals from the late Oligocene site of Chilga, Ethiopia. Acta Palaeontologica Polonica, 49, 365-392.

Seiffert, E., Nasir, S., Al-Harthy, A., Groenke, J., Kraatz, B., Stevens, N. \& Al-Sayigh, A. 2012. Diversity in the later Paleogene proboscidean radiation: a small barytheriid from the Oligocene of Dhofar Governorate, Sultanate of Oman. Naturwissenschaften, 1-9, doi: 10.1007/s00114011-0878-9.

Thomas, H., Roger, J., Sen, S. \& Al-Sulaimani, Z. 1992. Early Oligocene verebrates from Dhofar (Sultanate of Oman). Geology of the Arab World, Cairo University, Cairo, 283-293. 
Thomas, H., Roger, J., Sen, S., Bourdillon de Grissac, C. \& Al-Sulaimani, Z. 1989. Découverte de vertébrés fossiles dans l'Oligocène inférieur du Dhofar (Sultanat d'Oman). Geobios, 22, 101-120.

Thomas, H., Roger, J., Sen, S., Pickford, M., Gheerbrant, E., Al-Sulaimani, Z. \& Al-Busaidi, S. 1999. Oligocene and Miocene terrestrial vertebrates in the southern Arabian Peninsula (Sultanate of Oman) and their geodynamic and palaeogeographic settings. In: Fossil Vertebrates of Arabia (eds Whybrow, P. \& Hill, A.). Yale University Press, New Haven, 430-442.

Tobien, H. 1988. Contribution à l'étude du gisement miocène supérieur de Montredon (Hérault). Les grands mammifères. 7 - Les Proboscidiens Deinotheriidae. Palaeovertebrata, Mémoire extraordinaire, 135-175. 